\title{
Quantitative landscape dynamics in Denmark through the last three millennia based on the Landscape Reconstruction Algorithm approach
}

\author{
Anne Birgitte Nielsen · Bent Vad Odgaard
}

Received: 27 August 2009/Accepted: 3 November 2009

(C) The Author(s) 2010. This article is published with open access at Springerlink.com

\begin{abstract}
This paper explores the spatial and temporal land-cover variability within the main cultural landscape units in Denmark during the last 3,000 years. Quantitative estimates of the cover of trees, grasses, Cerealia and Calluna around nine Danish lakes were obtained using the recently developed Landscape Reconstruction Algorithm (LRA) (Sugita 2007a, b). The performance of the approach was evaluated by comparing reconstructed vegetation based on A.D. 1800 pollen spectra to land cover from historical maps of the same period. Although the model tended to overestimate grassland cover by $10-20 \%$, the reconstructed vegetation was much more similar to the observed than the uncorrected pollen proportions. The LRA was then applied to 3,000 year long pollen records to reconstruct the vegetation development around each of the nine sites. The results support earlier conclusions regarding the relative stability of woodland, agrarian and heathland dominated landscapes in Denmark (Odgaard and Rasmussen 2000), with the distribution of the main landscape types determined by topography and soil characteristics. The present study indicates that the transition zones between agricultural and forest dominated landscapes were the most dynamic, acting as buffer zones where most of the expansions and contractions
\end{abstract}

Communicated by T. Giesecke.

\section{A. B. Nielsen $(\varangle)$}

Department of Palynology and Climate Dynamics, Albrechtvon-Haller-Institute for Plant Sciences, University of Göttingen, Untere Karspüle 2, Göttingen 37073, Germany

e-mail: anne-birgitte.nielsen@biologie.uni-goettingen.de

B. V. Odgaard

Department of Earth Sciences, University of Aarhus, Høegh-Guldbergs Gade 2, Aarhus C 8000, Denmark e-mail: bent.odgaard@geo.au.dk of agricultural activities took place. The quantitative vegetation reconstructions underline the importance of farming and especially pastoral activities in shaping the Danish landscapes throughout the study period.

Keywords Pollen analysis - Lake sediments · Quantitative analysis · Landscape Reconstruction Algorithm · Late Holocene

\section{Introduction}

Evidence from fossil pollen data indicates that Europe has undergone substantial changes in land-cover since the midHolocene introduction of agriculture (e.g. Behre 1988; Lang 1994; Gaillard 2007). Through impacts on processes such as evapo-transpiration, changes in albedo, soil stabilization and acidification, mineralization and (de)nitrification, these changes have had strong affects on hydrology, terrestrial and fluvial erosion rates, nutrient cycles, climate and biodiversity (Bonan 2002). Quantitative estimates of past land cover changes are therefore not only of primary interest in terms of vegetation dynamics but also a potential link to the causes of associated environmental changes.

The pollen composition in sediments is a reflection of the vegetation in the surrounding landscape at the time of deposition. However, deriving a quantitative measure of vegetation cover from pollen percentage data is not straightforward. Some of the complicating factors include differential pollen production and pollen dispersal among plant species (Nielsen and Odgaard 2004).

Over the last decades, methods have been developed that allow us to distance weight vegetation data according to models of pollen dispersal and deposition (Prentice 1985; Sugita 1993); to estimate the relative pollen productivity of 
different plant taxa from pollen/vegetation calibration datasets (Parsons and Prentice 1981; Prentice and Parsons 1983; Sugita 1994) and to assess the source area of pollen for different basin types and sizes (Sugita 1994).

These methods have been applied in Denmark, using a historical calibration dataset of ca. A.D. 1800 pollen assemblages from 29 lakes and land cover from historical maps from the same period (Nielsen 2003). Pollen assemblages predicted by the Sugita (1993) pollen dispersal and deposition models were shown to resemble those observed in the lake sediments (Nielsen 2004). The relevant source area of the lakes was estimated to have a radius of 1,800-2,000 m, and was shown to depend mostly on the spatial structure of the surrounding vegetation (Nielsen and Sugita 2005). Also the relative pollen productivity of four plant groups: trees, cereals, grasses and Calluna, was determined, and these were shown to be useful for quantitative land cover reconstructions in the A.D. 1800 landscape (Nielsen and Odgaard 2005; Broström et al. 2008). These four plant groups can be considered some of the most important for describing the overall composition of the Danish cultural landscape, as they are the main constituents of woodlands, arable fields, grazing areas and heathlands, respectively.

In this study, we aim to apply the knowledge gained about the pollen productivity, dispersal and source area to subfossil pollen records from nine small lakes in Denmark using the Landscape Reconstruction Algorithm (LRA) proposed by Sugita $(2007 \mathrm{a}, \mathrm{b})$, in order to obtain quantitative estimates of the past composition of Danish cultural landscapes during the last 3,000 years.

For the Danish area, analyses of mid- and late Holocene pollen data suggest that the macro-scale structure of the classical cultural landscape had come into existence by 3000 B.P. (Odgaard and Rasmussen 2000). This meant a differentiation into (i) hilly districts with relatively frequent woodlands, (ii) landscapes on poor soils with extensive heathlands and (iii) flat terrain on fertile soils with dominant grasslands and arable fields. These three landscape units seem to have been relatively stable over the last three millennia and land-use was apparently strongly related to two important landscapes variables, topography and soil fertility (Odgaard and Rasmussen 2000).

In this paper we investigate the spatial and temporal variability within each of the three landscape units in the classical Danish cultural landscape. Specifically, we address the following questions: Were rapid land-cover changes characteristic for some landscape types while other types showed slow or little changes? What was the landscape position of buffer zones for expansion/contraction of agricultural activities?

\section{Methods}

Sites and data

Among Danish lake sites with existing pollen diagrams, nine study sites were selected for the interdisciplinary research project AGRAR 2000 (Odgaard and Rømer 2009) to represent the three main landscape types and variations therein. Store Gribs $\varnothing$, Avns $\varnothing$ and Store $\varnothing \mathrm{kss} \varnothing$ are located in regions which are relatively rich in woodland today and also were so around A.D. 1800 according to historical maps. Dallerup Sø, Gudme Sø and Gundsømagle Sø are located in regions dominated by agricultural areas, whereas Skaans $\varnothing$, Navns $\varnothing$ and Krags $\varnothing$ are located on sandy soils in western Jutland, characterised by large proportions of heathland by A.D. 1800 , although much of the heathland has since then been converted into arable land or conifer plantations. The sites are all medium sized lakes (areas shown in Table 1) similar to those used in the historical calibration dataset (Nielsen and Odgaard 2005), so they can be expected to have similar relevant pollen source areas. The lakes are all without major inlets.

The areas around the sites differ in soil types, topography and surrounding modern and historical vegetation. In relation to soils, the most important geological border in Denmark is the so called East-Jutland stationary line (Fig. 1) which was formed during the Young Baltic Ice
Table 1 Lake site characteristics

\begin{tabular}{lccl}
\hline Site & Area (ha) & Max depth $(\mathrm{m})$ & Original publication \\
\hline Avns $\varnothing$ & 4 & 8 & Nielsen (1999) \\
Dallerup S $\varnothing$ & 9 & 4 & Odgaard (1999b) \\
Store Gribs $\varnothing$ & 10 & 11 & Løvberg (unpublished) \\
Gudme S $\varnothing$ & 16 & 1 & Rasmussen and Olsen (2009) \\
Gunds $\varnothing$ magle S $\varnothing$ & 32 & 2 & Rasmussen et al. (1999) \\
Krags $\varnothing$ & 13 & 2 & Odgaard (1994) \\
Navns $\varnothing$ & 24 & 10 & Odgaard (1999a) \\
Skaans $\varnothing$ & 16 & 9 & Odgaard (1994) \\
Store $\varnothing \mathrm{kss} \varnothing$ & 41 & 7 & Odgaard (1999a) \\
\hline
\end{tabular}




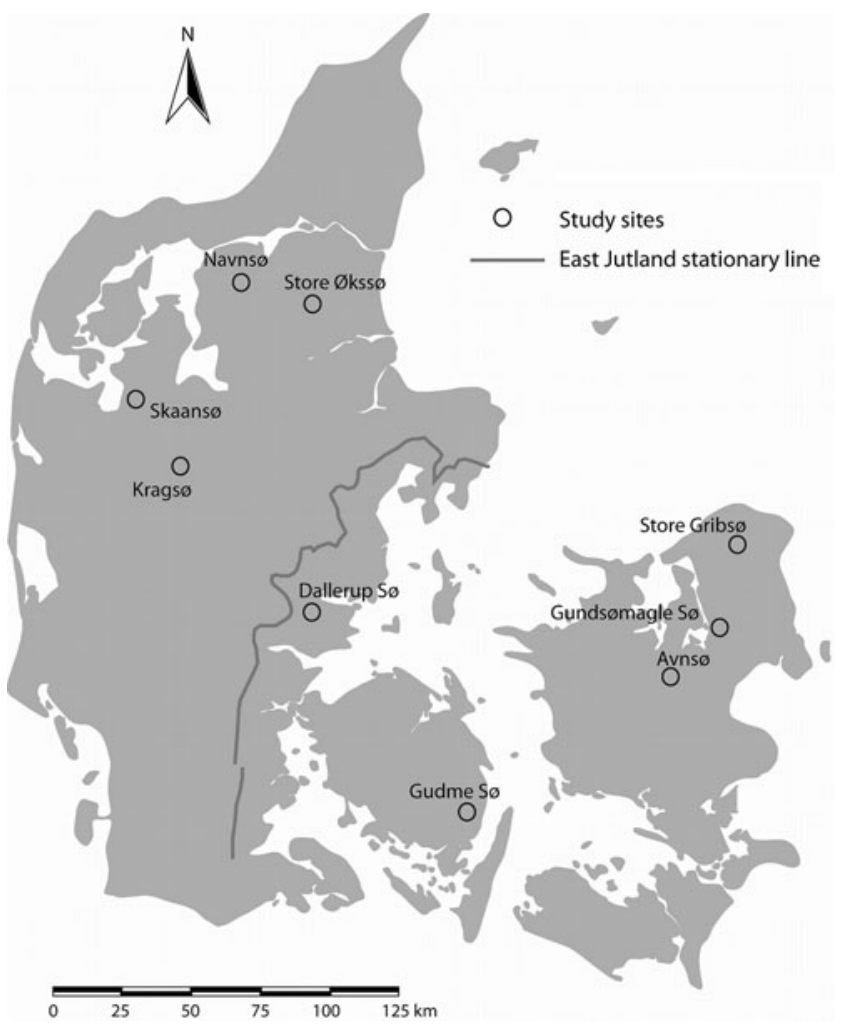

Fig. 1 Location of the nine study sites. The Eastern Jutland stationary line indicates the stationary line of the Young Baltic ice advance in 19000 B.P

advance about 19,000 B.P. The area east of this line is dominated by calcareous clayey tills while the area west and north of the line is dominated by outwash sands or sandy tills with rather low clay content. For the land-cover reconstructions, the East Jutland stationary line has been used to delimit a western from an eastern Danish region.

The chronological control on the pollen records differs among sites. For Store Gribsø (Løvberg, unpublished), the age-depth model is based on four ${ }^{14} \mathrm{C}$ dates in the period after A.D. 1, and 5 from the period between 1 and 4000 в.C. There has been no ${ }^{14} \mathrm{C}$ dating done on material from the Avnsø sediments (Nielsen 1999). Instead, the series is dated by correlation to other, well dated pollen diagrams. In particular, many features of the Avns $\emptyset$ diagram are also found in a well dated pollen diagram from Holmegårds mose (Aaby 1986), a large raised bog around $20 \mathrm{~km}$ from Avnsø. These features include the sharp rise in Fagus between 1000 and 900 в.C., the first occurrence of Secale around 100 B.c. and the first occurrence of Centaurea cyanus around A.D. 1250 . There have been several ${ }^{14} \mathrm{C}$ datings made on plant remains from the core from Store $\emptyset \mathrm{kss} \varnothing$ (Odgaard 1999a), but most of them showed erroneous ages due to the influence of re-deposited charcoal in the samples. Thus, the age depth model for Store Økss $\emptyset$ is based on few dates, the youngest from A.D. 690, and correlation to other, dated pollen diagrams from the same region. The time scale for Dallerup $\mathrm{S} \varnothing$ is based on six ${ }^{14} \mathrm{C}$ dates throughout the last 2,500 years. The youngest reliable data is from A.D. 1420, while the sediments from the 20th century were dated by the occurrence of spherical soot particles originating from the burning of coal and oil (Odgaard 1993). The number of ${ }^{14} \mathrm{C}$ dates from Gudme $\mathrm{S} \varnothing$ is six within the last 3,000 years, of which three are from 1000 to 1 в.c. The youngest reliable date is from A.D. 890 . The sediment of Gudme $\$ \varnothing$ is slightly calcareous, but although the dates were carried out on bulk samples, the chronology seems reliable within ca. 100 years (Rasmussen and Olsen 2009). Despite repeated efforts it has proved impossible to obtain reliable ${ }^{14} \mathrm{C}$ dates from the sediments of Gundsømagle $\mathrm{S} \varnothing$, and the age depth model is therefore based on correlation with other pollen diagrams, using the same markers as mentioned for Avns $\varnothing$ (Rasmussen and Anderson 2005). The top $94 \mathrm{~cm}$ of sediment was dated using an assay of ${ }^{210} \mathrm{~Pb}$ and ${ }^{137} \mathrm{Cs}$ (Rasmussen and Anderson 2005). The age depth model for Skaans $\varnothing$ for the period A.D. $1-2000$ is based on eight ${ }^{14} \mathrm{C}$ dates, the youngest of which was dated to A.D. 1166 (Odgaard 1994). From Navns $\emptyset$, there are no reliable ${ }^{14} \mathrm{C}$ dates younger than A.D. 130 , due to the lack of datable terrestrial plant material in the cores. This series is thus mainly dated by correlation to dated pollen diagrams in the same region. The age depth model for the Krags $\varnothing$ core is also, due to a lack of datable material from the last 2,000 years based on only four ${ }^{14} \mathrm{C}$ dates, the youngest of which is from A.D. 308, together with correlation to other pollen diagrams from Jutland and on the rise in spherical soot particles (Odgaard 1994).

\section{The Landscape Reconstruction Algorithm}

The LRA is a method proposed by Sugita $(2007 a$, b) to reconstruct past vegetation composition using pollen percentage data from a network of sites. The present study is the first attempt to apply the LRA to fossil pollen records from Denmark.

The method comprises two steps: REVEALS and LOVE. In REVEALS (Regional Estimates of VEgetation Abundance from Large Sites; Sugita 2007a) past regional plant abundance is estimated from pollen percentage data by taking into account the relative pollen productivity of different plant species and the differential dispersal of different pollen types. The REVEALS model is similar to the R-value model (Davis 1963), with the added inclusion of the pollen dispersal coefficient of each taxon. The model aims at reconstructing vegetation abundance within an entire region, so background pollen loading coming from outside the region is ignored, unlike the Extended R-value models (Parsons and Prentice 1981; Prentice and Parsons 1983; Sugita 1994), where regional background pollen 
loading is included. The formula for the REVEALS model is (Sugita 2007a):

$\hat{V}_{i}=\frac{n_{i, k} / \hat{\alpha}_{i} \int_{R}^{Z_{\max }} g_{i}(z) d z}{\sum_{j=1}^{t} n_{j, k} / \hat{\alpha}_{i} \int_{R}^{Z_{\max }} g_{j}(z) d z}$

where $\hat{V}_{i}$ is an estimate of the proportion of the regional vegetation composed of species i, $n_{i, k}$ is the pollen count of species $\mathrm{i}$ at site $\mathrm{k}, \hat{\alpha}_{i}$ is the estimate of the relative pollen productivity of species $\mathrm{i}, \mathrm{R}$ is the radius of the basin, $Z_{\max }$ is the maximum extent of the regional vegetation, $\mathrm{z}$ is the distance from the centre of the basin, $g_{i}(z)$ is the pollen dispersal and deposition model of species $i$ and $t$ is the total number of species included in the analysis.

Simulation experiments (Sugita 2007a) have shown that the most reliable estimate of the regional vegetation composition is obtained by using pollen assemblages from large lakes, typically $>100-500$ ha, because the site to site variation in pollen assemblages from such sites is expected to be small. However, an average estimate based on multiple smaller sites within a region can also be used to reconstruct regional plant abundance, albeit with larger error estimates. Here, we applied REVEALS to pollen data from the nine study sites. From each site, the pollen proportions were averaged over 500 year intervals before the application of REVEALS. The nine study sites were split into two groups, i.e. the sites located east (five sites) and west (four sites) of the East Jutland stationary line (Fig. 1), as regional vegetation is highly affected by differences in soil types. For each subset, the regional plant abundance estimates and their variance and covariance were calculated in 500 year intervals from 1000 B.C. to A.D. 2000, using the software REVEALS.v4.1.8 (Sugita, unpublished).

The pollen dispersal function for each pollen type considered must be known, and estimates of relative pollen productivity must be available before REVEALS can be applied. In this study, we used the Ring Source model of pollen dispersal and deposition (Sugita et al. 1999), assuming a wind speed of $3 \mathrm{~m} / \mathrm{s}$, neutral atmospheric conditions and the fall speeds for the pollen types listed in Table 2. The relative pollen productivity of Cerealia, Poaceae, Calluna and trees (with all tree species considered as one group) were determined from a calibration dataset of ca. A.D. 1800 pollen samples and land cover from historical maps (Nielsen and Odgaard 2005) and are also listed in
Table 2. Their variance-covariance matrix was included in the analysis in order to obtain error estimates on the regional vegetation composition.

The second step in the LRA approach is the application of the LOVE (LOcal Vegetation Estimation) model (Sugita $2007 \mathrm{~b}$ ) to reconstruct local vegetation within the relevant source area (Sugita 1994) of individual sites. LOVE is derived from the inverse form of ERV model 2 (Prentice and Parsons 1983). However, where the ERV model assumes that the pollen loading for each species coming from outside the relevant source area is constant, LOVE makes allowance for variations in this regional background pollen loading over time, by estimating these based on the regional plant abundance estimates obtained with REVEALS. This overcomes one of the main limitations of applying not only the inverse ERV models but also other methods, such as multivariate calibrations and modern analogue techniques for reconstruction of past vegetation where not only the local, but also the regional vegetation composition differs from the present. The LOVE model allows the vegetation proportion of species $i$ within the relevant source area of site $k, v_{i k}$ to be estimated using the following expression (Sugita 2007b):

$\hat{v}_{i, k}=\frac{\frac{n_{i, k}}{\hat{\alpha}_{i}}}{\sum_{j=1}^{t} \frac{n_{j, k}}{\hat{\alpha}_{j}}}\left(1+\sum_{j=1}^{t} \hat{S}_{j}\right)-\hat{S}_{i}$

where $\hat{S}_{i} \equiv \frac{\hat{V}_{i} \int_{Z_{\mathrm{RSAP}}}^{Z_{\max }} g_{i}(z) d z}{\sum_{j=1}^{t} \hat{V}_{j} \int_{R}^{Z_{\mathrm{RSAP}}} g_{i}(z) d z}$ and $Z_{\mathrm{RSAP}}$ is the radius of the relevant source area of pollen. The other terms are as defined for the REVEALS model (see above).

Thus the necessary input parameters to the LOVE model include the pollen dispersal model and estimates of relative pollen productivity as for REVEALS and the size of the relevant source area for the site under consideration. Here we assumed a relevant source area with a radius of $1,800 \mathrm{~m}$, which is the size estimated for the lakes in the Danish calibration dataset (Nielsen and Sugita 2005). The calculations were carried out using the software LRA.LOVE.v3.1.3 (Sugita, unpublished). In instances where the estimated plant abundance of one or more taxa was negative, the relevant source area for the LOVE calculations was increased until the estimates of all taxa were $\geq 0$, considering a $0.1 \mathrm{SD}$ threshold. The program uses a hybrid method of error propagation and Monte Carlo simulations
Table 2 Fall speed of pollen, pollen productivity estimates relative to Cerealia and standard deviation of pollen productivity estimates (Nielsen and Odgaard 2005)

\begin{tabular}{llll}
\hline Pollen type or group & Fall speed $(\mathrm{m} / \mathrm{s})$ & $\begin{array}{l}\text { Relative pollen } \\
\text { productivity estimate }\end{array}$ & SD \\
\hline Cerealia & 0.060 (Gregory 1973) & 1 & 0 \\
Trees & 0.035 (Nielsen 2004) & 10.161 & 0.305 \\
Poaceae & 0.035 (Eisenhut 1961) & 1.060 & 0.150 \\
Calluna & 0.038 (Broström 2002) & 2.156 & 0.121 \\
\hline
\end{tabular}


to estimate standard error on the vegetation composition estimates (Sugita 2007b).

\section{Results}

Model evaluation

To test the performance of the LRA for reconstructing vegetation, LOVE reconstructed vegetation composition for A.D. 1800 is compared to distance weighted vegetation composition in the pollen source area of the nine study sites derived from historical maps from the same period (Nielsen and Odgaard 2005). The performance of REVEALS for reconstructing regional vegetation is more difficult to assess, because historical land cover is not available for the whole region in the same detail as for the local areas around the lakes. The performance of REVEALS has, however, been tested using modern vegetation data and surface pollen samples from large lakes in southern Sweden (Hellman 2005; Hellman et al. 2008a, b).

Figure 2 shows the relationship between distance weighted plant abundance, as observed on the historical maps, and pollen proportion at the nine study sites (left column) as well as the relationship between observed plant proportions and A.D. 1800 plant abundance reconstructed using the LOVE model (right column). Particularly for trees and for Cerealia, the relationship between reconstructed and observed vegetation is much closer to a oneto-one relationship. Many of the reconstructions fall with one standard error of the 1:1 line, but not all. The proportion of tree cover is slightly underestimated at the woodland rich sites, but not to the same degree as woodland might be overestimated at the woodland poor sites if only the raw pollen proportions were considered. For Poaceae, there is a tendency for the plant proportion to be overestimated by $10-20 \%$ by the LOVE model, whereas the pollen proportions tend to be lower than the vegetation proportions. The error estimates of the reconstructed proportions of Poaceae are large, due to a large standard error on the relative pollen productivity estimate for Poaceae (Nielsen and Odgaard 2005). The occurrence of grasses, especially Phragmites australis in reed beds along the lake shores may have been contributing to the overestimation of grass cover in the landscape, as such communities are not depicted on the historical maps. For Calluna, both the raw pollen proportions and the LOVE reconstructed vegetation are generally similar to the observed Calluna cover in this dataset.

Overall, the reconstruction corresponds much better with the observed vegetation than the raw pollen proportions do, but the tendency for overestimation of Poaceae

\section{Trees}
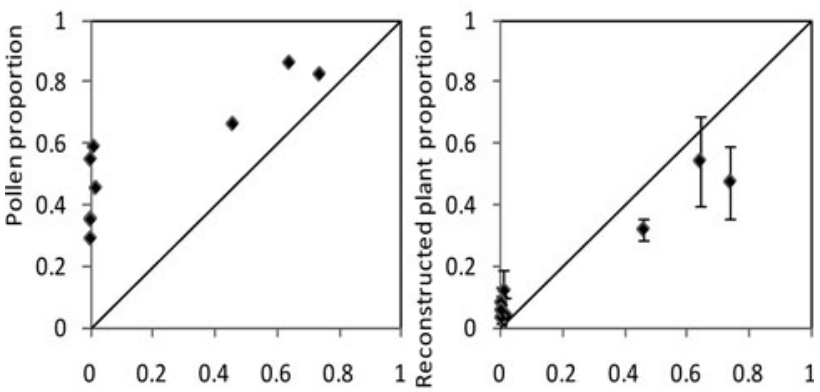

Poaceae
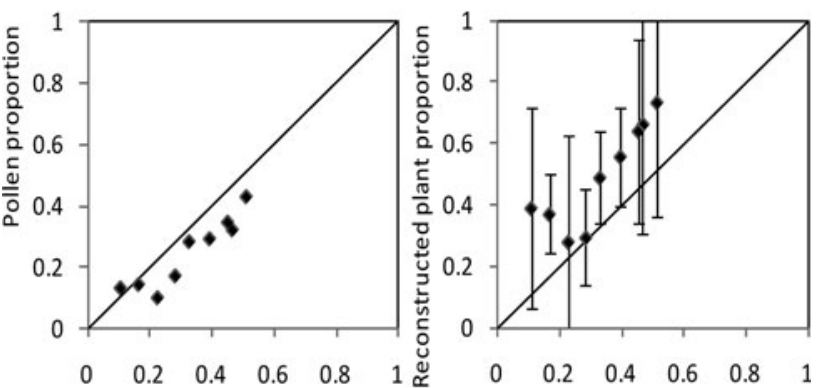

Calluna
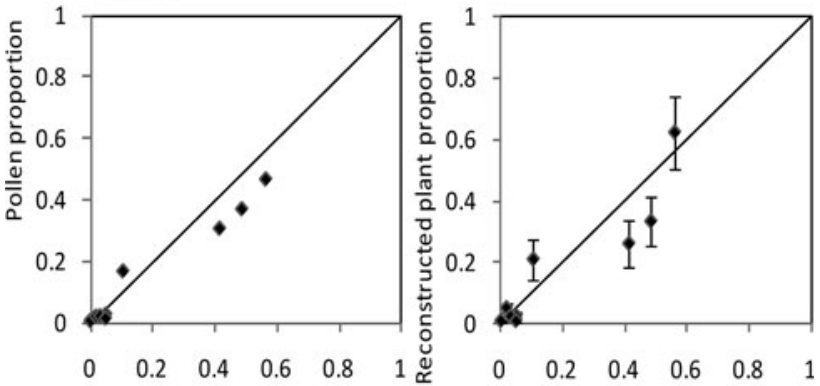

Cerealia

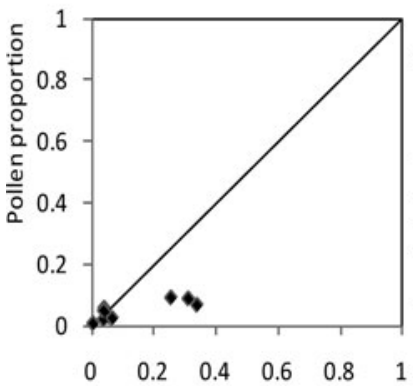

Observed distance weighted plant proportion

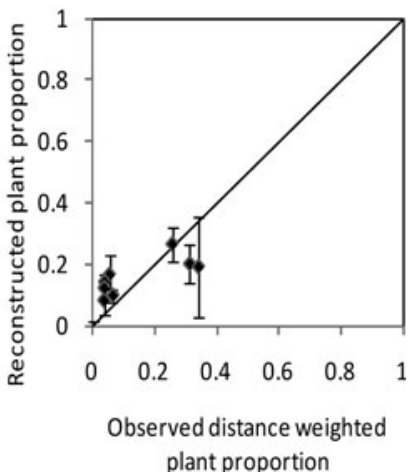

Fig. 2 Uncorrected A.D. 1800 pollen proportions (left column) and A.D. 1800 plant abundance reconstructed using the LOVE model (right column) plotted against distance weighted plant abundance based on percentage cover, as observed on the historical maps from A.D. 1800 for the nine study sites. The sum of the four pollen groups was used as the basis for percentage calculation. Standard errors are shown for the plant abundance estimates

cover and underestimation of tree cover at tree rich sites should be kept in mind when interpreting the vegetation reconstructions further back in time. 
Regional plant abundance

Figure 3 shows the regional plant composition east and west of the East Jutland stationary line in six 500-year intervals since 1000 B.C., reconstructed using the REVEALS model. These estimates were in turn used as input for the LOVE model for individual sites and samples.

In eastern Denmark, the area of cereal cultivation increased gradually through the 3,000 year period. In contrast, tree covered area generally decreased, but increased slightly in the period A.D. 500-1000. Grassland increased around 500 B.C., then decreased around A.D. 500 and has increased since. The area covered by Calluna was always low in this region where the species is mostly restricted to bogs and poor fens.

On the poorer sandy soils in western Denmark the area with cereals was low until around A.D. 500 but increased gradually. Regional tree cover decreased through the whole period, and was throughout lower than in eastern Denmark. The area of grass cover decreased slightly during the first 1,000 years and has remained stable since. The Calluna covered area expanded until A.D. 1500 and on average decreased a bit in the most recent 500 year period reflecting the cultivation of many heathland areas during the last 200 years.

\section{A: Eastern Denmark}

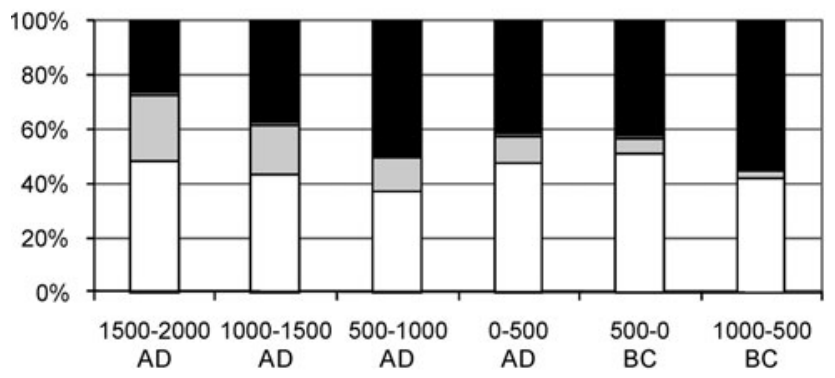

B: Western Denmark

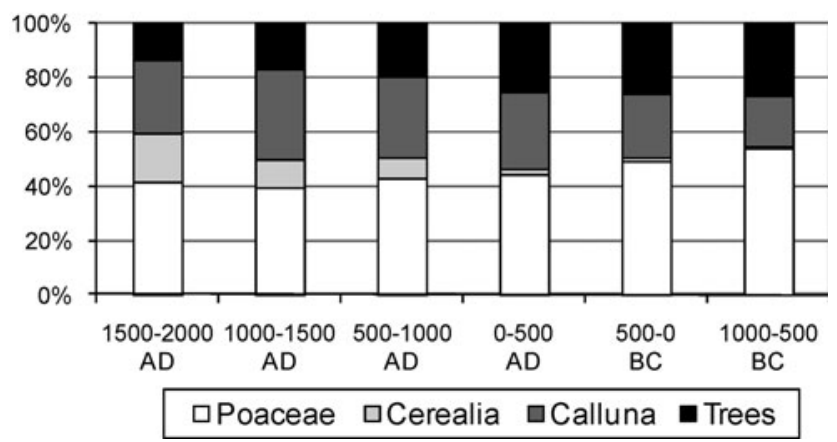

Fig. 3 Regional vegetation composition east and west of the East Jutland stationary line in 500 year intervals for the last 3,000 years as estimated using the REVEALS model
Local development in land cover from 1000 B.C.

to A.D. 2000

\section{Store Gribsф}

The reconstruction based on the Store Gribsø pollen record (Fig. 4) shows that the area around the lake was modestly influenced by agricultural activities during the last 3,000 years. Thus, woodland dominated the landscape throughout the period and although the presence of pollen from grasses and Plantago lanceolata as well as from Hordeum type and Secale reflects some human impact, this influence is much lower than at most other investigated sites in the Danish islands (e.g. Rasmussen 2005; Rasmussen and Anderson 2005; Rasmussen and Olsen 2009). The dominant tree during the last three millennia was Fagus, but Alnus, Betula and Quercus were also important. The woodland cover was dense until about 700 B.C. when there was an expansion of grassland and to a lesser extent of arable land. Around the Birth of Christ, some 50\% of the landscape was covered by grassland, but after this there was a re-expansion of woodland, which accelerated during the period A.D. 400-700. Until ca. A.D. 1000 the tree cover was dense, but there were still some arable fields. From the early medieval period onwards the grassland area expanded, most strongly from A.D. 1200-1300. The landscape

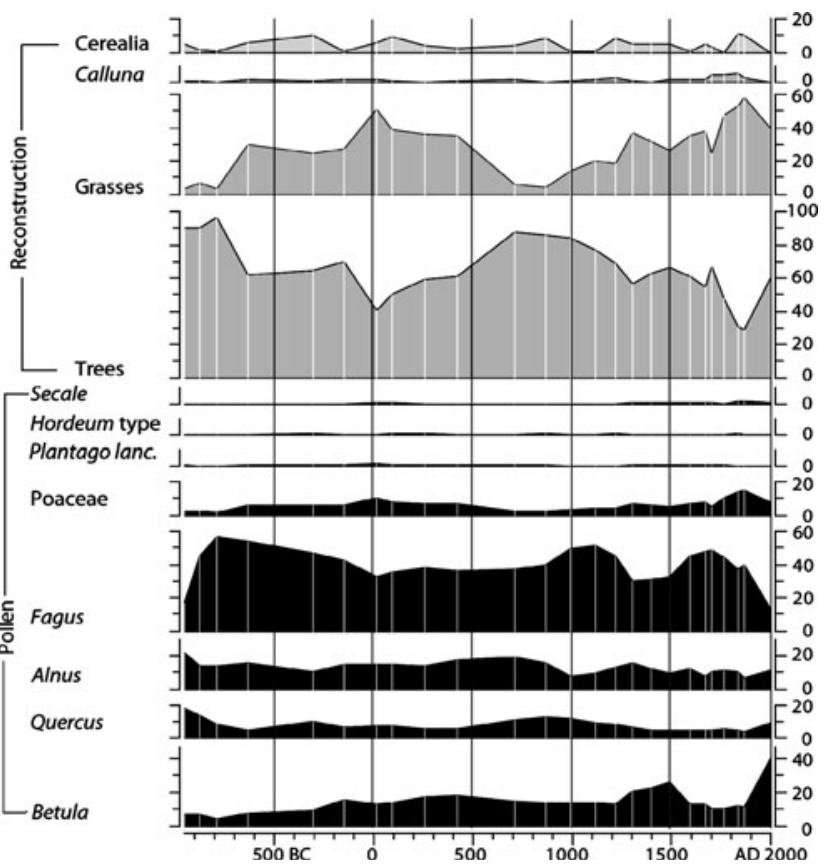

Fig. 4 Store Gribsø. LRA-reconstruction of the cover of cereals, heather, grasses and trees through the last 3,000 years. A selection of frequencies (percentage of terrestrial pollen) of the more important pollen types is also shown 
around Store Gribsø was at its most open around A.D. 1800, when there were also some areas covered by Calluna.

Avns $\phi$

Around Avnsø (Fig. 5) as for the Store Gribsø area, there was a high degree of woodland cover during the last 3,000 years although a general trend towards decreased tree cover is reflected during the period. Fagus was the dominant tree, but Quercus, Alnus and Corylus were also prominent. The amount of grass pollen is low compared to other sites in Denmark (Odgaard 2006), and the same is true for Plantago lanceolata and cereal pollen, including Secale. Just after 1000 B.C. the woodland cover was very dense but from around 500 B.c. the area of grassland increased. The grassland was probably found as commons used for grazing of livestock. These pasture areas were prominent until ca. A.D. 700 when woodland cover increased in the area. This probably reflects a less intensive use of the landscape for grazing. From around A.D. 1100 the grassland area expanded again and at this time the cultivated area also increased. Until then, cereal cultivation had been of minor importance in the Avns $\varnothing$ area. Around A.D. 1500 a decline in cereal cultivation is reflected in the record. Because of the relatively poor time control of the Avnsø series, this change may well correspond to a late medieval crisis following the Black Death in the mid 14th century. The tree covered area declined from the

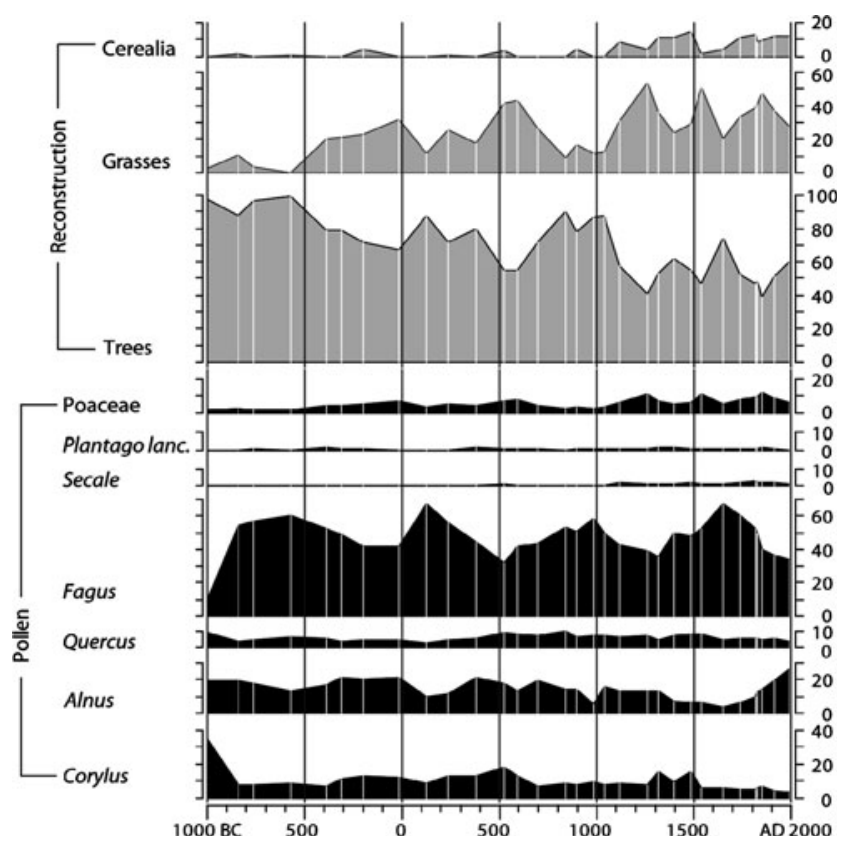

Fig. 5 Avns $\emptyset$. LRA-reconstruction of the cover of cereals, grasses and trees through the last 3,000 years. A selection of frequencies (percentage of terrestrial pollen) of the more important pollen types is also shown seventeenth to the 19th century, until the Danish Forest Act of 1805 that prohibited grazing in the forests began to take effect.

\section{Store $\emptyset k s s \emptyset$}

The area was characterised by an intermediate, but quite stable woodland cover during the last 3,000 years (Fig. 6). Grasslands, however, were the dominant element in the landscape, and Calluna-dominated heathlands were also prominent throughout. Despite the extensive grasslands the pollen proportion of Plantago lanceolata was not very high, no doubt due to the poor, sandy soils in the region, as this species prefers more nutrient rich soils. The dominant tree species were Betula, Quercus, Corylus, Alnus and Fagus, the latter showing large fluctuations in frequency. Fagus did not become prominent in the landscape around Store $\varnothing \mathrm{kss} \emptyset$ until at about A.D. 1400. It is likely, that the demographic and social changes following the plague in the 14th century lead to a decrease in grazing pressure which favoured Fagus, allowing it to expand. A decline in Plantago lanceolata pollen and a peak in the pioneer plant Salix (not shown in diagram) immediately before the rise in Fagus support this interpretation. A similar but short-lived Fagus expansion is seen during the 2 nd century A.D. At that time, however, there was no decline in Plantago lanceolata pollen. Except for these fluctuations of Fagus, and declines in grassland area when Fagus expanded, the area is

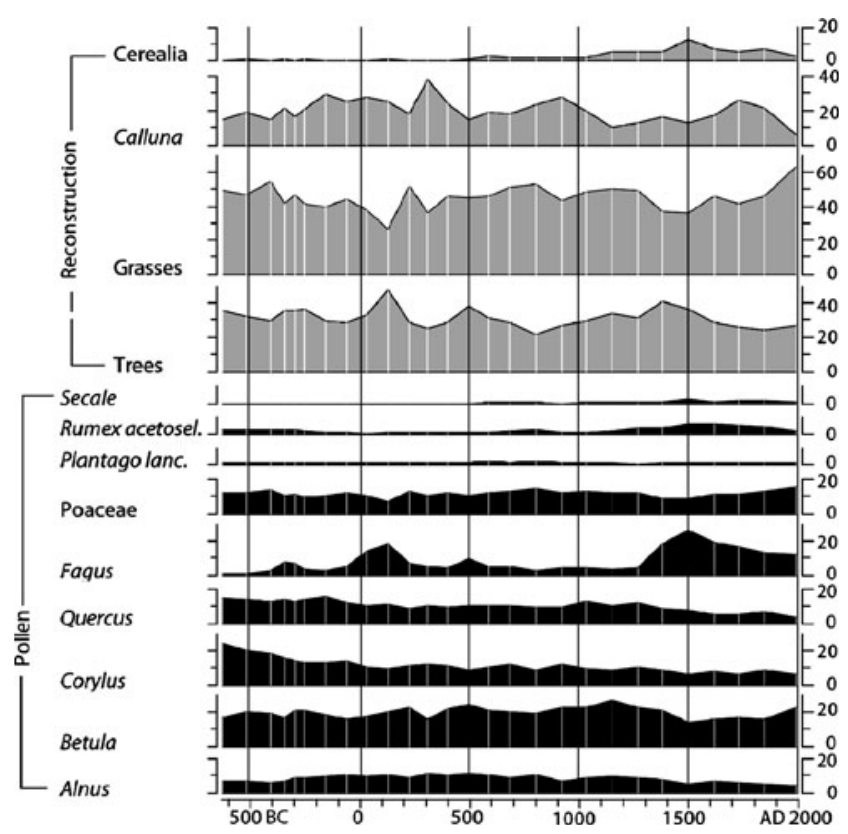

Fig. 6 Store $\varnothing \mathrm{kss} \emptyset$. LRA-reconstruction of the cover of cereals, heather, grasses and trees through the last 3,000 years. A selection of frequencies (percentage of terrestrial pollen) of the more important pollen types is also shown 
characterised by relative stability. For example, there were no signs of a marked woodland expansion between A.D. 600 and 1000, as it is seen at Avns $\varnothing$ and Store Gribsø as well as at Dallerup $S \varnothing$ and Gudme $S \varnothing$ (see below). The relative stability during this period at Store Økss $\varnothing$ resembles the pattern seen in the heathland dominated areas around Navns $\varnothing$, Krags $\varnothing$ and Skaans $\varnothing$. Cereal cultivation was not prominent in the Store $\varnothing \mathrm{kss} \varnothing$ area until the 12th century A.D. and onwards, and the decline in heathlands during the same period could indicate that former heathland areas were turned into arable land. The abundant Rumex acetosella pollen reflects the preference of this species for fields with winter rye.

\section{Dallerup $S \phi$}

The Dallerup Sø record (Fig. 7) reflects a landscape dominated by agriculture through the last 3,000 years in which tree cover has been less extensive. The woodlands that did occur in the area were mostly found on wet soils, as indicated by the dominance of Alnus. Quercus and sometimes also Fagus were also prominent in the woodlands. Together with Poaceae, Plantago lanceolata was very abundant in the landscape, and despite the relatively fertile soils some Calluna also occurred.

In the beginning of the last millennium B.C. woodland dominated the landscape, but around 500 в.с. an extensive change of the landscape took place, whereby the woodlands

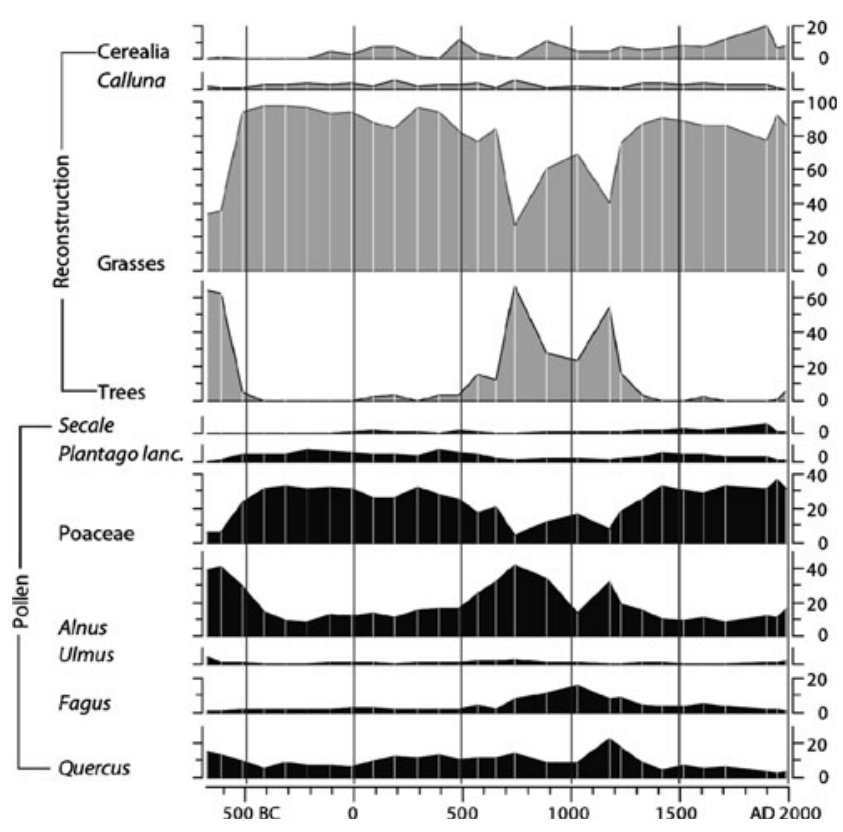

Fig. 7 Dallerup Sø. LRA-reconstruction of the cover of cereals, heather, grasses and trees through the last 3,000 years. A selection of frequencies (percentage of terrestrial pollen) of the more important pollen types is also shown almost disappeared from the surroundings of the lake. Instead, grass-dominated areas spread, and the landscape must have been heavily impacted by grazing livestock. From at least 200 B.c. arable fields also featured in the landscape, although they only made up a small part of the area. From A.D. 600 to 700 there was a strong expansion of woodland, probably partly in the very close surroundings of the lake itself. It was first Alnus, then Ulmus, Fagus and Quercus, which reacted. The fact that both Alnus and Fagus became more abundant shows that tree cover increased both on the wet soils and on the drier ones. This was most likely due to a decrease in grazing pressure or perhaps a concentration of the grazing animals in smaller, limited areas. The area with cereal cultivation also declined in this period. From A.D. 700-1000 a new woodland decline is seen which is again replaced by woodland expansion in the period A.D. 1100-1200. During the latter phase, there seems to be little, if any, decline of arable fields. Immediately following A.D. 1200 , grassland areas expanded and became dominant in the landscape once again. The cultivated area increased from the early 17 th century until the end of the 19th century, after which there seems to be a decline, accompanied by an increase in grassland.

\section{Gudme $S \phi$}

The pollen record (Fig. 8) from Gudme Sø shows an intermediate situation with heavy impact by grazing animals during the last 3,000 years, but also some woodland cover throughout. The dominant trees were Fagus, Alnus, Corylus and Quercus, while Plantago lanceolata was abundant in the grasslands. The period before A.D. 200 was characterised by dominant grassland cover, while arable fields played only a minor role in the landscape. After A.D. 200 there was a small expansion of woodland, apparently by Fagus on upland soils. From A.D. 400 the woodland declined again, this time mainly involving Alnus, which indicate clearings of woodland on wet ground, possibly for hay meadows. During the period A.D. $600-900$ there was a clear expansion of woodland, primarily involving Fagus and Alnus. After this, there was an expansion of grasslands and also cereal cultivation increased. On the most nutrientpoor pastures some Calluna was found.

\section{Gundsømagle $S \phi$}

The reconstruction of the landscape development around Gundsømagle $S \varnothing$ (Fig. 9) indicates that the area is unique in a Danish context through the overwhelming dominance of grassland areas during the last 3,000 years and the already large proportion of cereal pollen in the period A.D. 1-600. This situation reflects a greater importance of Iron Age cereal cultivation than is known from any other 


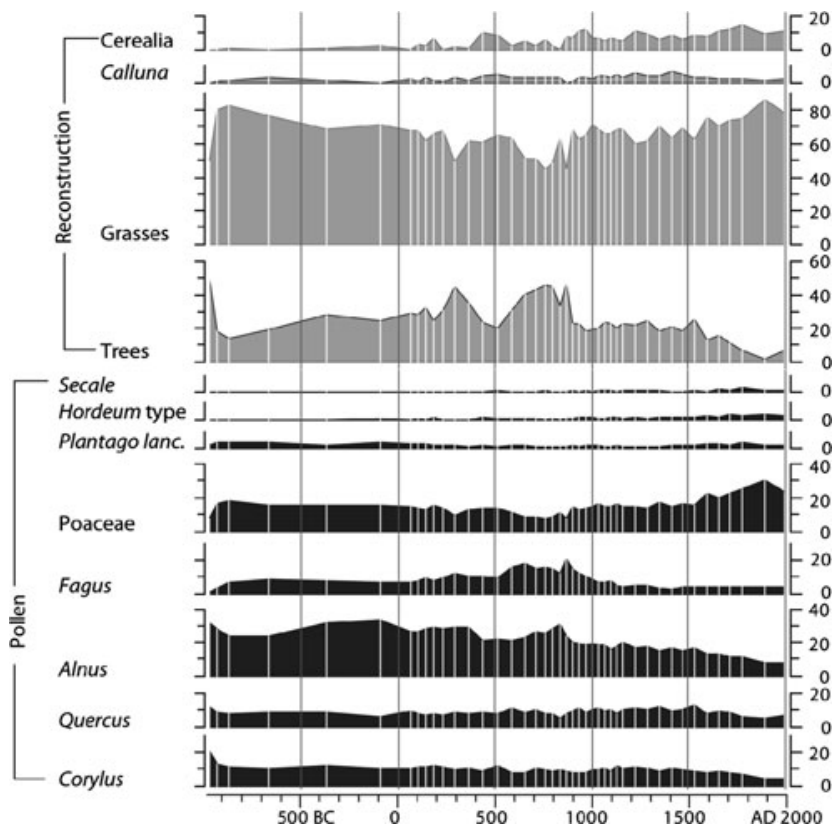

Fig. 8 Gudme S $\emptyset$. LRA-reconstruction of the cover of cereals, heather, grasses and trees through the last 3,000 years. A selection of frequencies (percentage of terrestrial pollen) of the more important pollen types is also shown

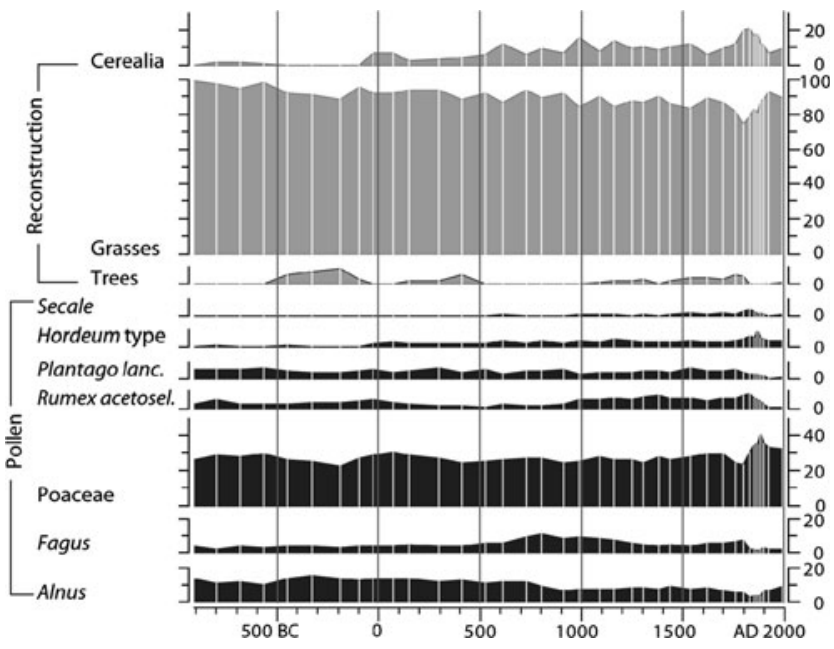

Fig. 9 Gundsømagle Sø. LRA-reconstruction of the cover of cereals, grasses and trees through the last 3,000 years. A selection of frequencies (percentage of terrestrial pollen) of the more important pollen types is also shown

Danish pollen record. It is evident that this area has been optimal for farming, and woodland has been virtually absent during the entire 3,000 year period considered here. Apart from increasing arable farming the only small sign of change during this period is a slight increase in the pollen frequencies for Fagus, but this is probably due to increased long distance transport from areas where the species expanded, such as the area around Avns $\varnothing$, some $30 \mathrm{~km}$ southwest of Gundsømagle. Pastures with Plantago lanceolata persisted throughout the period, even while arable fields expanded. Plantago lanceolata could, however, also have grown in hay meadows which were presumably widespread in the area, characterised by extensive wetlands.

\section{Skaans $\phi$}

Throughout the last three millennia the Skaans $\varnothing$ area (Fig. 10) was characterised by heathland and grassland, while woodlands were subordinate and generally decreasing. A radius of $1,800 \mathrm{~m}$ around Skaans $\emptyset$ includes almost exclusively glacial outwash plain with only insignificant amounts of moraines so the pollen record mainly reflects the vegetation on sandy, nutrient-poor soils. The dominant trees in what little woodland there was were Betula and Quercus, with Alnus on the moist soils. Fagus probably never occurred naturally in the area around Skaans $\varnothing$. The prevailing development during the period from 1000 в.с. to A.D. 1500 was a general expansion of heathlands and a corresponding decline in grassland. This change probably reflects a gradual leaching of nutrients from the soil, while the dynamics over shorter time spans depended on the frequency of burning of the vegetation: the more frequent the fires, the more Calluna became dominant (Odgaard 1994). Burning, reflected by ample charred particles in the sediments, was used as a means to rejuvenate the

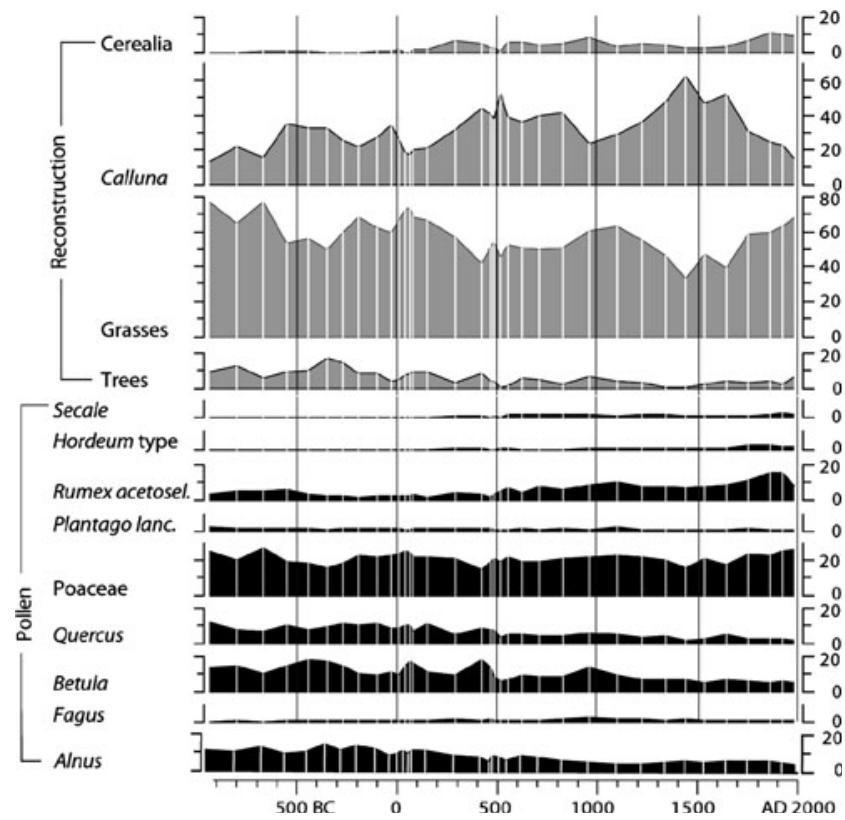

Fig. 10 Skaans $\varnothing$. LRA-reconstruction of the cover of cereals, heather, grasses and trees through the last 3,000 years. A selection of frequencies (percentage of terrestrial pollen) of the more important pollen types is also shown 
heathland, providing young heather suitable for winter grazing. Cereal cultivation was quite widespread in the area from ca A.D. 200 onwards. After A.D. 600 Secale was probably the dominant crop, and in the fallow fields Rumex acetosella was abundant. As in the other heathland lakes, there is no sign of a decline in grazing intensity during the A.D. $600-1000$ period.

\section{Navnsø}

The landscape development in the Navns $\varnothing$ area (Fig. 11) is similar to the pattern observed at Skaans $\varnothing$, in that heathland and grassland are the dominant landscape elements throughout the last three millennia. Likewise, there is a gradual change towards more heathland and less grassland and woodland throughout the period. The most important trees were Quercus, Betula and Alnus whereas Fagus hardly ever occurred near Navnsø. During the last millennium B.c. there was an expansion of heathland at the expense of grassland. Another heathland expansion occurred between A.D. 600 and 1000, also at the expense of grassland and this time also of woodland. Along with the decline of grassland there was also a decline in the proportion of Plantago lanceolata pollen. The area with cereal cultivation expanded from around A.D. 1200. Secale was the main crop and Rumex acetosella was very abundant through the last 800 years.

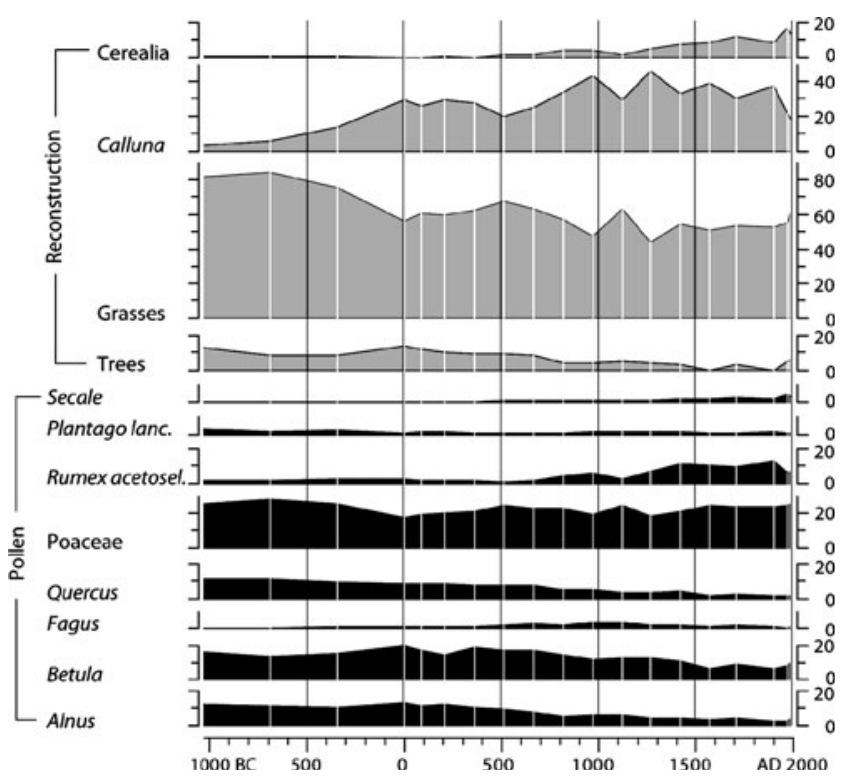

Fig. 11 Navns $\varnothing$. LRA-reconstruction of the cover of cereals, heather, grasses and trees through the last 3,000 years. A selection of frequencies (percentage of terrestrial pollen) of the more important pollen types is also shown

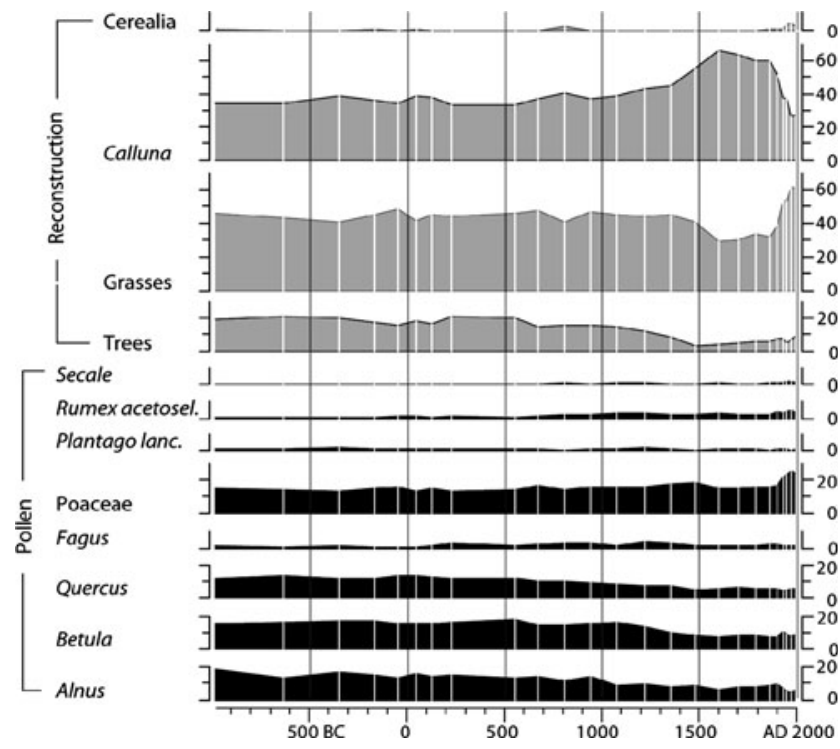

Fig. 12 Krags $\varnothing$. LRA-reconstruction of the cover of cereals, heather, grasses and trees through the last 3,000 years. A selection of frequencies (percentage of terrestrial pollen) of the more important pollen types is also shown

\section{Krags $\phi$}

Despite the fact that poor soils in Denmark generally supported little forest during the last three millennia (Odgaard 2006) some woodland of Betula and Quercus persisted until quite recently on the very poor and coarse sands in the Krags $\varnothing$ area, with Alnus on the wetter soils (Fig. 12). The main landscape elements, however, were grassland and heathland. Secale pollen does occur, but only in small amounts that can be explained as regional background pollen coming from outside the relevant source area of pollen. Thus, cereal cultivation seems to have been of very little importance in the area. The vegetation composition was quite stable until the 13th century. During the period from ca. A.D. 1400-1600 heathlands expanded at the expense of grassland and woodland. From the early 19th century heathlands declined again, and was replaced by grassland and some arable land.

\section{Discussion}

Landscape development

The results of this study corroborate earlier conclusions regarding the relative stability of woodland, agrarian and heathland landscapes throughout the last 3,000 years (Odgaard and Rasmussen 2000). The new results are, however, based on quantitative reconstructions with a theoretically sounder basis as vegetation proxies than raw pollen percentages. Also, the quantitative estimates allow 
more secure identification of landscapes with rapid versus slow change rates. Store Gribs $\emptyset$, Avns $\varnothing$ and Store $\varnothing \mathrm{kss} \varnothing$ all had fairly large amounts of woodland in their surroundings throughout the 3,000 year period. The areas around Dallerup Sø, Gudme Sø and Gundsømagle Sø had little woodland cover for most or all of the period, but were instead dominated by grassland vegetation with some arable fields with cereals. Also the Skaans $\varnothing$, Krags $\varnothing$ and Navns $\varnothing$ areas had little woodland, but were dominated by a mixture of grass and Calluna heathlands. The proportion of the areas used for cereal cultivation was smaller than on the more fertile soils in the agricultural landscapes.

\section{Woodland landscapes}

Those areas of Denmark which have retained a relatively high woodland cover throughout the last 3,000 years, such as north-eastern Zealand (Store Gribsø), central Zealand (Avns $\varnothing$ ) and eastern Himmerland (Store $\emptyset \mathrm{kss} \varnothing$ ), are characterised by hilly terrains, which can only be cultivated with difficulty. While some of these regions have relatively sandy soils the area around Avns $\varnothing$ is characterised by fairly fertile soils underlining the importance of topography for the choice of areas for cultivation by prehistoric and historic farmers.

The woodland areas also provided important resources, such as timber, firewood and leaf fodder, and provided areas for forest grazing, hunting and at least in later periods, areas for feeding pigs on mast. For agriculture, these areas were generally marginal and they were less influenced by variations in agricultural intensity than certain other landscape types. However, even at Store Gribs $\varnothing$ and Avns $\varnothing$ the increased woodland cover during the period A.D. 600-1000 was evident. Also the medieval expansion of non-forested areas was pronounced although it seems to have been delayed until the 14 th- 15 th century in these areas. At Store $\varnothing \mathrm{kss} \emptyset$ these variations are not evident.

A characteristic pattern in the woodland landscapes was the early and rapid expansion of Fagus, in many places on Zealand and Funen already becoming the dominant woodland tree during the Bronze Age. Here, the limited cultural impact on the woodlands seemed to favour Fagus and allowed for rapid expansion. One exception is the landscape around Store $\varnothing \mathrm{kss} \emptyset$, where Fagus did not really expand until the medieval period. This medieval Fagus expansion was perhaps a result of a decrease in landscape impact by animal husbandry following decimation of the human population during the Black Death.

\section{Agricultural landscapes}

In contrast to the hilly woodland landscapes, flatter landscapes with fertile soils were dominated by farming activities throughout the 3,000 year period. Typical examples include areas of central Zealand (Gundsømagle Sø), northern Funen (Rasmussen 2005) and those parts of Thy in north-western Jutland which were not affected by sand drift (Andersen 1993). In these areas the cultural impact was very strong, and often began vigorously as early as around 2600 B.C., in the middle Neolithic. The land-cover development in these areas can be described as a steady trend towards less woodland but more pasture and, especially later, more arable land.

Less typical were those areas situated in the border zone between hilly terrain and flat, fertile areas, as found around Gudme Sø and Dallerup Sø. The landscape development in these border areas was more dynamic, with large variations in cultivation and grazing intensity. It appears that these border zones formed the buffers into which farming could be extended during periods of economic expansion, while contracting during periods of unrest, population decline or weaker economies. These dynamics caused marked variations in woodland area. At Gudme Sø and Dallerup S $\varnothing$ there was a large expansion of woodland after A.D. 600 and an equally large expansion of agricultural areas during the medieval period, especially around A.D. 1200-1400 (A.D. 900-1300 at Gudme $\mathrm{S} \varnothing)$. However, even in these border zone areas there was a general trend towards more cereal cultivation during the last 2,000 years, similar to the more typical and central agricultural areas referred to above.

\section{Heathland landscapes}

The areas with very sandy and nutrient-poor soils found especially in western Jutland did not offer the same possibilities for agriculture as did the eastern Danish landscapes. However, farming practices involving fire management and winter grazing were adapted to the conditions, and the intensity of the cultural impact on the landscape was not necessarily lower than elsewhere. In some places, the first destruction of the original rather open woodlands began as early as in the fifth millennium B.P., when heathlands began to spread (Odgaard 1994). This heathland expansion was not primarily driven by leaching of soil nutrients due to agriculture but mainly by controlled burning of vegetation to provide heathland for grazing purposes. Studies of pollen and charcoal in sediment cores point to a very close relationship between burning and the amount of heathland (Odgaard 1992, 1994). At the same time, results show that heathlands were kept in young Calluna-dominated stages while not being allowed to develop into the Empetrum heathlands with invasion of trees and shrubs so often seen today (Riis-Nielsen et al. 2005). The purpose of the fire management was probably to achieve a mix of grasses and young Calluna plants, 
providing both summer and winter grazing. Heathlands were an important resource of the cultural landscape.

The heathland landscapes were not strongly affected by the fluctuations seen in the border zones between agricultural and woodland landscapes. In contrast, during the period A.D. 600-1000 when woodland expanded in the border zone and most woodland landscapes, the heathland sites showed expansions of heathland and reductions in woodland, in other words an intensification of farming impact. The heathland landscapes supported some sparse woodland until the beginning of the medieval period, and the results from Kragsø indicate that woodland persisted longest in the most nutrient-poor, sandy areas with indications of forest remnants until after the end of the medieval period.

\section{Conclusions}

Changes in cultural landscape land-cover are often caused by a complex mixture of social, economic and technological developments. However, such changes are constrained by the physical landscape itself, i.e. by geology, geomorphology and soils. The physical constraints of the three dominant Danish landscapes since 3000 в.P. until industrialized farming began are very clear and can be represented by soil fertility and topography in a simple diagram (Fig. 13). Soil fertility, in Denmark mainly controlled by clay and silt content (Callesen and Raulund-Rasmussen 2004), determined whether grassland or heathland were the optimal resources for domestic grazing. Also, soil fertility together with topography controlled the preferred location of arable fields.

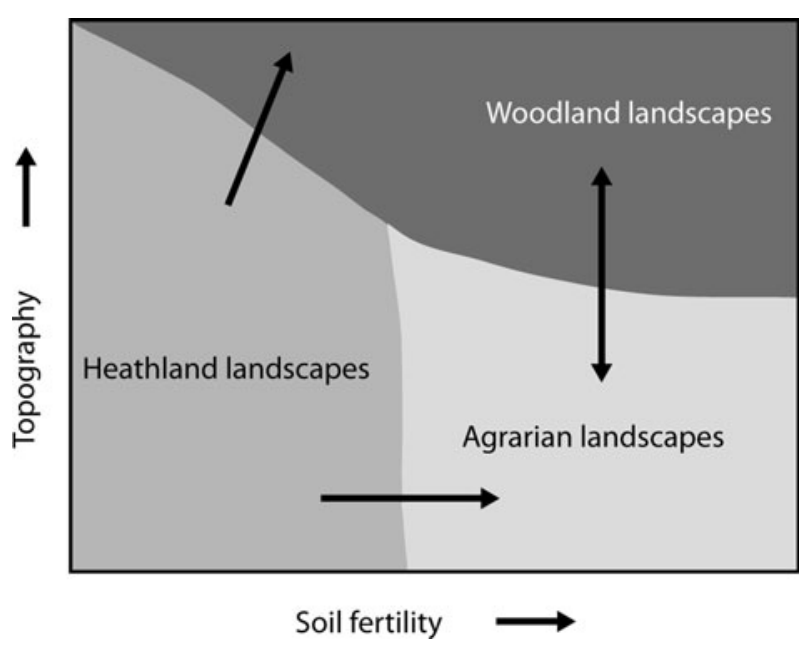

Fig. 13 A model of the landscape situation of the three major landscape types during the period 1000 B.C.-A.D. 1800 as controlled by topography and soil fertility. The arrows indicate the direction of changes through the period
In such a soil/topography diagram (Fig. 13) woodland landscapes of the period 1000 B.C.-A.D. 1800 occur in the top part, relatively independent of soils. The agricultural landscapes are in the right lower part while the heathland landscapes occupy the left part. While it is true that the three landscape types were relatively stable in their characteristics, quite a number of changes did occur. First, heathlands tended to expand into woodland and agricultural landscapes as a result of changes in land-use and perhaps also progressive soil leaching. Secondly, a period of expanding forest cover can be identified during the period A.D. 400-800. In contrast, forest decreased during A.D. $800-1200$. These dynamics were seen in woodland as well as in agricultural landscapes but most strongly expressed in the border zone between the two. However, is seems to have affected only landscapes on relatively fertile soils, as it is not seen in the Store Økss $\varnothing$ area or any of the heathland sites. Heathland landscapes showed a slow but progressive forest reduction throughout the period 1000 B.C.-A.D. 1800 .

This first application of the LRA in Denmark has provided new insights into the overall composition and the degree of openness of the cultural landscape and its development over the past 3,000 year period, throughout which all Danish landscapes have been heavily impacted by agricultural and especially pastoral activities, resulting in a dominance of grassland on fertile soils and a mixture of grass and Calluna heathlands on sandy soils.

Despite a tendency for the LRA-model to underestimate tree cover and overestimate grass cover, it is now clear that the degree of openness of the landscapes during the last 3,000 years was much higher than it appears from uncorrected percentage pollen diagrams, and that much of the Danish landscape has been very poor in forest cover throughout this period.

Acknowledgements We thank Peter Rasmussen and Tina Løvberg for access to raw pollen data. We are also very thankful to Shinya Sugita for use of his unpublished software and to all members of the POLLANDCAL network for useful and inspiring discussions during the numerous network workshops held between 2002 and 2009. This work was done as part of the multidisciplinary project "AGRAR 2000. Agrarian landscapes from the Birth of Christ to the 21st century." AGRAR 2000 was supported by the previous four Danish national foundations for Sciences, for Humanities, for Agricultural Sciences and for Social Sciences. Kari Hjelle and an anonymous reviewer are thanked for their constructive and useful comments to the manuscript. We dedicate this contribution to Sheila Hicks for her life-long devoted involvement in palaeoecology during which she has been an extraordinary role model for generations of young researchers.

Open Access This article is distributed under the terms of the Creative Commons Attribution Noncommercial License which permits any noncommercial use, distribution, and reproduction in any medium, provided the original author(s) and source are credited. 


\section{References}

Aaby B (1986) Trees as anthropogenic indicators in regional pollen diagrams from eastern Denmark. In: Behre K-E (ed) Anthropogenic indicators in pollen diagrams. Balkema, Rotterdam, pp 7394

Andersen ST (1993) History of vegetation and agriculture at Hassing Huse Mose, Thy, northwest Denmark, since the Ice Age. J Dan Archaeol 11:57-79

Behre K-E (1988) The role of man in European vegetation history. In: Huntley B, Webb T III (eds) Vegetation history-handbook of vegetation science 7. Kluwer, Dordrecht, pp 633-672

Bonan G (2002) Ecological climatology. Cambridge University Press, Cambridge

Broström A (2002) Estimating source area of pollen and pollen productivity in the cultural landscapes of southern Swedendeveloping a palynological tool for quantifying past plant cover. Doctoral thesis, Lund University

Broström A, Nielsen AB, Gaillard M-J, Hjelle K, Mazier F, Binney H, Bunting J, Fyfe R, Meltsov V, Poska A, Räsänen S, Soepboer W, von Stedingk H, Suutari H, Sugita S (2008) Pollen productivity estimates of key European plant taxa for quantitative reconstruction of past vegetation: a review. Veget Hist Archaeobot 17: 461-478

Callesen I, Raulund-Rasmussen K (2004) Base cation, aluminum, and phosphorus release potential in Danish forest soils. J Plant Nutr Soil Sci 167:169-177

Davis MB (1963) On the theory of pollen analysis. Am J Sci 261:897-912

Eisenhut G (1961) Untersuchungen über die Morphologie und Ökologie der Pollenkörner heimischer und fremdländischer Waldbäume. Paul Parey, Hamburg

Gaillard M-J (2007) Pollen. Archaeological applications. In: Elias SA (ed) Encyclopedia of quat science. Elsevier, Amsterdam, pp 2571-2595

Gregory PH (1973) The microbiology of the atmosphere. Leonard Hill, Aylesbury

Hellman SEV (2005) Quantitative reconstruction of past cultural landscapes in Southern Sweden, 3000-0 BP: validation of a modelling approach to estimate regional plant abundance in Skåne and Småland. The ESS Bulletin 3:60

Hellman S, Gaillard M-J, Broström A, Sugita S (2008a) The REVEALS model, a new tool to estimate past regional plant abundance from pollen data in large lakes: validation in southern Sweden. J Quat Sci 23:21-42

Hellman SEV, Gaillard M-J, Broström A, Sugita S (2008b) Effects of the sampling design and selection of parameter values on pollenbased qualitative reconstructions of regional vegetations: a case study in southern Sweden using the REVEALS model. Veget Hist Archaeobot 17:445-459

Lang G (1994) Quartäre Vegetationsgeschichte Europas. Fischer, Jena

Nielsen AB (1999) Vegetationshistorien i området omkring Avnsø på Midtsjælland -belyst ved pollenanalyse. Masters thesis, University of Copenhagen

Nielsen AB (2003) Pollen based quantitative estimation of land cover-relationships between pollen sedimentation in lakes and land cover as seen on historical maps in Denmark AD 1800. Danmarks og Grønlands Geologiske Undersøgelse Rapport 2003/57. GEUS, Copenhagen

Nielsen AB (2004) Modelling pollen sedimentation in Danish lakes around AD 1800 - an attempt to validate the POLLSCAPE model. J Biogeogr 31:1693-1709

Nielsen AB, Odgaard BV (2004) The use of historical analogues for interpreting fossil pollen records. Veget Hist Archaeobot 13: $33-43$
Nielsen AB, Odgaard BV (2005) Reconstructing land cover from pollen assemblages from small lakes in Denmark. Rev Palaeobot Palynol 133:1-21

Nielsen AB, Sugita S (2005) Estimating relevant source area of pollen for small Danish lakes around AD 1800. Holocene 15:1,0061,020

Odgaard BV (1992) The fire history of Danish heathland areas as reflected by pollen and charred particles in lake sediments. Holocene 2:218-226

Odgaard BV (1993) The sedimentary record of spheroidal carbonaceous fly-ash particles in shallow Danish lakes. J Paleolimnol 8:171-187

Odgaard BV (1994) The Holocene vegetation history of northern West Jutland, Denmark. Opera Bot 123:1-171

Odgaard BV (1999a) Fossil pollen as a record of past biodiversity. J Biogeogr 26:7-17

Odgaard BV (1999b) Pollenanalytiske undersøgelser 1998 Pollenanalyser fra Dallerup Sø, Østjylland. Danmarks og Grønlands Geologiske Unders øgelse Rapport 1999/14. GEUS, Copenhagen

Odgaard BV (2006) Fra bondestenalder til nutid. In: Larsen G (ed) Naturen i Danmark-Geologien. Gyldendal, Copenhagen, pp 333-359

Odgaard BV, Rasmussen P (2000) Origin and temporal development of macro-scale vegetation patterns in the cultural landscape of Denmark. J Ecol 88:733-748

Odgaard BV, Rømer JR (2009) Danske landbrugslandskaber gennem 2000 år-Fra digevoldinger til støtteordninger. Aarhus University Press, Aarhus

Parsons RW, Prentice IC (1981) Statistical approaches to R-values and pollen-vegetation relationship. Rev Palaeobot Palynol 32:127-152

Prentice IC (1985) Pollen representation, source area, and basin size: toward a unified theory of pollen analysis. Quat Res 23:76-86

Prentice IC, Parsons RW (1983) Maximum likelihood linear calibration of pollen spectra in terms of forest composition. Biometrics 39:1,051-1,057

Rasmussen P (2005) Mid- to late-Holocene land-use change and lake development at Dallund S $\varnothing$, Denmark: vegetation and land-use history inferred from pollen data. Holocene 15:1,116-1,129

Rasmussen P, Anderson NJ (2005) Natural and anthropogenic forcing of aquatic macrophyte development in a shallow Danish lake during the last 7000 years. J Biogeogr 32:1,993-2,005

Rasmussen P, Olsen J (2009) Soil erosion and land-use change during the last six millennia recorded in lake sediments of Gudme $\mathrm{S} \emptyset$, Fyn, Denmark. Geol Surv Den Greenl Bull 17:37-40

Rasmussen P, Hansen HJ, Nielsen LB (1999) Kulturlandskabet i et langtidsperspektiv. To sjællandske områder gennem de sidste 6000 år. Nationalmuseets Arbejdsmark 1998:101-113

Riis-Nielsen T, Schmidt IK, Frandsen B, Binding T (2005) Nørholm Hede. En langtidsundersøgelse af hedens vegetationsudvikling og tilgroning. Forest Landsc Res 35:1-202

Sugita S (1993) A model of pollen source area for an entire lake surface. Quat Res 39:239-244

Sugita S (1994) Pollen representation of vegetation in quaternary sediments: theory and method in patchy vegetation. J Ecol 82:881-897

Sugita S (2007a) Theory of quantitative reconstruction of vegetation I. Pollen from large sites REVEALS regional vegetation composition. Holocene 17:229-241

Sugita S (2007b) Theory of quantitative reconstruction of vegetation. II. All you need is LOVE. Holocene 17:243-257

Sugita S, Gaillard M-J, Broström A (1999) Landscape openness and pollen records: a simulation approach. Holocene 9:409-421 